\title{
DESKRIPSI MODEL PEMBELAJARAN DISCOVERY KURIKULUM 2013 DALAM MATERI MENULIS TEKS LAPORAN HASIL OBSERVASI SISWA KELAS X IPA 1 SMA NEGERI 4 LEBONG
}

\author{
${ }^{1}$ Maharini, ${ }^{2}$ Gumono, ${ }^{3}$ M. Arifin \\ ${ }^{1,2,3}$ Universitas Bengkulu
}

Korespondensi: maharini2212@gmail.com

\begin{abstract}
ABSTRAK
Tujuan penelitian ini untuk mengetahui bagaimana deskripsi model pembelajaran Discovery Kurikulum 2013 dalam materi menulis teks laporan hasil observasi siswa kelas X IPA 1 SMA Negeri 4 Lebong. Penelitian ini menggunakan metode deskriptif dengan pendekatan kualitatif. Data dalam penelitian ini adalah ujaran guru dan ujaran siswa yang diperoleh dari hasil pengamatan penulis terhadap aktivitas belajar siswa dikelas X IPA 1 SMA Negeri 4 Lebong menggunakan model pembelajaran Discovery. Sumber data dalam penelitian ini adalah guru Bahasa Indonesia dan siswa kelas X IPA 1 SMA Negeri 4 Lebong. Teknik pengumpulan data dalam penelitian ini menggunakan teknik observasi, wawancara, dokumentasi dan rekaman. Teknik analisis data yang digunakan dalam penelitian ini yaitu reduksi data, penyajian data, verifikasi. Hasil penelitian ini yaitu guru Bahasa Indonesia menggunakan model pembelajaran discovery pada pelajaran Bahasa Indonesia materi teks laporan hasil observasi di kelas X IPA 1 SMA Negeri 4 Lebong. Akan tetapi tidak semua sintaks model pembelajaran discovery digunakan guru pada saat proses belajar mengajar berlangsung. Pada pertemuan pertama dengan topik materi mengidentifikasi isi teks laporan hasil observasi guru menggunakan semua sintaks model pembelajaran discovery, pada pertemuan kedua dengan topik materi mengidentifikasi struktur teks laporan hasil observasi guru tidak menggunakan salah satu sintaks model pembelajaran discovery yaitu pembuktian. Pada pertemuan ketiga dengan topik materi mengidentifikasi unsur kebahasaan teks laporan hasil observasi guru tidak menggunakan dua sintaks model pembelajaran discovery yaitu pengumpulan data dan pembuktian.
\end{abstract}

Kata kunci: model, pembelajaran discovery, teks laporan hasil observasi.

\section{Abstract}

The purpose of this study was to find out how the description of the 2013 Discovery Curriculum learning model in the material written in the observation report of class X IPA 1 students of SMA Negeri 4 Lebong. This study uses a descriptive method with a qualitative approach. The data in this study were the teacher's speech and the students 'speech which was obtained from the observation of the students' learning activities in class X IPA 1 SMA Negeri 4 Lebong using the Discovery learning model. Sources of data in this study were Indonesian language teachers and students of class X IPA 1 SMA Negeri 4 Lebong. Technique of data in research using observation, interview, documentation and recording techniques. The data analysis techniques used in this study were data reduction, data presentation, and levers. The results of this study were Indonesian teachers using discovery learning models in Indonesian lessons, text observation reports in class X IPA 1 SMA Negeri 4 
Lebong. However, not all discovery learning syntax models are used by the teacher during the teaching and learning process. At the first meeting with the topic that identified the contents of the teacher's observation report using all discovery learning syntax learning models, at the second meeting the identified topic of the teacher's observation report structure did not use one of the discovery learning syntax models, namely proof. In the third meeting with the topic that identified the linguistic elements of the text of the teacher's observation report, it did not use two discovery learning model syntaxes, namely data and proof.

Keywords: model, discovery learning, observation report text.

\section{PENDAHULUAN}

Salah satu tuntutan dan tantangan yang dihadapi dunia pendidikan pada saat ini dan kedepan adalah pendidikan hendaknya mampu menghasilkan sumber daya manusia yang memiliki kompetensi yang utuh, yaitu kompetensi sikap, kompetensi pengetahuan, dan kompetensi keterampilan yang terintegrasi. Kurikulum 2013 merupakan kurikulum yang diterapkan untuk menggantikan kurikulum sebelumnya yaitu Kurikulum Tingkat Satuan Pendidikan (KTSP). Kurikulum 2013 merupakan kurikulum berbasis kompetensi dengan memperkuat proses pembelajaran dan penilaian autentik untuk mencapai kompetensi sikap, pengetahuan dan keterampilan. Penguatan proses pembelajaran dilakukan melalui pendekatan santifik, yaitu pembelajaran yang mendorong siswa lebih mampu dalam mengamati, menanya, mencoba/mengumpulkan data, mengasosiasi/menalar, dan mengomunikasikan (Majid dan Rochman, 2015:1-2).

Karakteristik pembelajaran pada setiap satuan pendidikan terkait erat pada Standar Kompetensi Kelulusan dan Standar Isi. Standar Kompetensi Lulusan memberikan kerangka konseptual tentang sasaran pembelajaran yang harus dicapai. Standar Isi memberikan kerangka konseptual tentang kegiatan belajar dan pembelajaran yang diturunkan dari tingkat kompetensi dan ruang lingkup materi. Sesuai dengan Standar Kompetensi Lulusan, sasaran pembelajaran mecakup pengembangan ranah sikap, pengetahuan dan keterampilan yang dielaborasi untuk setiap satuan pendidikan. Ketiga ranah kompetensi tersebut memiliki lintasan perolehan (proses psikologi) yang berbeda. Karakteristik kompetensi beserta perbedaan lintasan perolehan turut serta memengaruhi karakteristik standar proses. Penguatan pendekatan saintifik perlu diterapkan pembelajaran berbasis penemuan (discovery learning) (Majid dan Rochman, 2015:2).

Menurut Majid dan Rochman (2015) Kurikulum 2013 untuk mata pelajaran Bahasa Indonesia menggunakan teks sebagai sarana pembelajaran. Oleh karena itu, dapat dinyatakan bahwa Kurikulum 2013 untuk mata pelajaran Bahasa Indonesia berbasis teks. Materi yang disajikan berupa teks yang dapat memberikan dan meningkatkan daya imajinasi peserta didik sehingga pelajaran Bahasa Indonesia tidak hanya sebagai mata pelajaran umum, melainkan sebagai penghela mata pelajaran lainnya.

Pembelajaran kurikulum 2013 terdapat beberapa unsur, yaitu pendekatan pembelajaran, strategi pembelajaran, metode pembelajaran dan model pembelajaran. Pendekatan pembelajaran adalah sudut pandang kita terhadap proses pembelajaran, yang merujuk pada pandangan tentang terjadinya suatu proses yang sifatnya masih sangat umum, di dalamnya mewadahi, menginsiprasi, menguatkan, dan melatari metode pembelajaran dengan cakupan teoretis tertentu. Strategi pembelajaran adalah suatu kegiatan pembelajaran yang harus dikerjakan guru dan siswa agar tujuan pembelajaran dapat dicapai secara efektif dan efisien, strategi pembelajaran bisa disebut juga sebagai 
perencanaan. Strategi pembelajaran adalah suatu perencanaan dan pelaksanaan yang bersifat sistematis untuk meningkatkan mutu dan kualitas pembelajaran. Metode pembelajaran adalah cara yang digunakan untuk mengimplementasikan rencana yang sudah disusun dalam bentuk kegiatan nyata dan praktis untuk mencapai tujuan pembelajaran, misalnya melalui ceramah, demonstrasi, diskusi, simulasi dan sebagainya. Model pembelajaran adalah bentuk pembelajaran yang tergambar dari awal sampai akhir yang disajikan secara khas oleh guru.

Pembelajaran discovery dalam penelitian ini adalah suatu model pembelajaran dengan cara peserta didik tidak langsung dihadapkan pada hasil akhir dari pembelajaran, namun peserta didik dituntut untuk dapat menemukan sendiri hasil akhir pembelajaran melalui rangsangan berupa pertanyaan-pertanyaan yang merangsang dan mengarahkan peserta didik untuk berpikir. Dalam penelitian ini model pembelajaran discovery merupakan model pembelajaran yang memiliki ciri pembelajaran berupa sintaks atau langkah-langkah model pembelajaran discovery.

Saat ini sekolah sudah menerapkan kurikulum 2013 yang memiliki prinsip pembelajaran yang menekankan pada perubahan paradigma yaitu siswa diberitahu menjadi siswa mencari tahu, guru hanya satu-satunya sumber belajar menjadi guru sebagai fasilitator. Berdasarkan hasil pengamatan, SMA Negeri 4 Lebong pada tahun 2004-2005 awalnya merupakan kelas jauh dari SMA Negeri 1 Lebong Selatan. Pada tahun 2006 sekolah ini sudah menerima siswa baru, yang telepas dari kelas jauh SMA Negeri 1 Lebong Selatan. Pada awal permulaan berdirinya lembaga pendidikan ini benama SMA Negeri 1 Rimbo Pengadang, kemudian berubah nama menjadi SMA Negeri 1 Topos, dan setelah beralih status ke Provinsi berubah nama menjadi SMA Negeri 4 Lebong sampai saat ini dan sudah menerapkan kurikulum 2013. Sejalan dengan kurikulum 2013, model pembelajaran discovery bisa digunakan terutama dalam pelajaran Bahasa Indonesia berbasis teks. Guru Bahasa Indonesia di SMA Negeri 4 Lebong menggunakan beberapa model pembelajaran, salah satunya model pembelajaran discovery, berdasarkan hal tersebut maka penulis ingin mendeskripsikan model pembelajaran discovery pada pelajaran Bahasa Indonesia Kurikulum 2013 dalam materi menulis teks laporan hasil observasi siswa kelas X IPA 1 SMA Negeri 4 Lebong.

Penelitian yang serupa dengan ini sudah pernah dilakukan oleh Mery Nazar dengan judul penelitian Pengarub Penggunaan Model Discovery Learning Terbadap Keterampilan Menulis Teks Prosedur Siswa Kelas XI SMA Negeri 3 Padang. Hasil penelitian ini yaitu keterampilan menulis teks prosedur sesudah menggunakan model pembelajaran Discovery Learning terdapat pengaruh yang signifikan, hal ini terlihat pada hasil belajar siswa menjadi lebih efektif.

Penelitian yang serupa dengan ini juga pernah diteliti oleh Rega Chandra Irawan dengan judul penelitian Implementasi Model Pembelajaran Discovery Learning Guna Meningkatkan Keaktifan Belajar Dan Minat Baca Siswa Kelas X Teknik. Kendaraan Ringan SMK Negei 1 Sedayu. Hasil penelitian ini adalah model pembelajaran Discovery Learning dapat meningkatkan keaktifan belajar dan minat baca peserta didik kelas X TKR A SMKN Sedayu Bantul. Hal ini terbukti dengan meningkatnya presentase keaktifan belajar peserta didik.

Rumusan masalah dalam penelitian ini adalah bagaimanakah deskripsi model pembelajaran Discovery Kurikulum 2013 dalam materi menulis teks laporan hasil observasi siswa kelas X IPA 1 SMA Negeri 4 Lebong. Berdasarkan rumusan masalah yang telah di 
uraikan, tujuan penelitian ini untuk mengetahui bagaimana deskripsi model pembelajaran Discovery Kurikulum 2013 dalam materi menulis teks laporan hasil observasi siswa kelas X IPA 1 SMA Negeri 4 Lebong.

Pada penelitian ini menggunakan teori Sefuddin dan Berdiati (2014:56) model pembelajaran discovery adalah metode mengajar yang mengatur pengajaran sedemikian rupa sehingga anak memperoleh pengetahuan yang sebelumnya belum diketahuinya itu tidak melalui pemberitahuan, sebagian atau seluruhnya ditemukan sendiri. Pembelajaran Discovery merupakan model pembelajaran yang disajikan oleh guru dengan memberikan rangsangan atau pemicu pada peserta didik agar daya nalar dan daya pikir peserta didik teroptimalkan. Model pembelajaran Discovery didefinisikan sebagai proses pembelajaran yang terhajadi bila pembelajar tidak disajikan dengan pelajaran dalam bentuk finalnya, tetapi melalui proses menemukan. Guru berperan sebagai pembimbing dengan memberikan kesempatan kepada peserta didik untuk belajar secara aktif, sebagaimana pendapat guru harus dapat membimbing dan mengarahkan kegiatan belajar peserta didik sesuai dengan tujuan.

Pembelajaran discoveFberdiary sebagai suatu prosedur mengajar yang mementingkan pengajaran seseorang, manipulasi objek dan lain-lain percobaan, sebelum sampai pada generalisasi. Sebelum peserta didik sadar akan pengertian, guru tidak menjelaskan dengan kata-kata. Model ini merupakan komponen dari paktik pendidikan yang meliputi metode mengajar yang memajukan cara belajar aktif, berorientasi pada proses, mengarahkan sendiri, mencari sendiri dan reflektif. (Suryosubroto, 2002:192).

J.Richard (dalam Roestiyah, 2012:20) menyatakan bahwa Discovery Learning adalah suatu cara mengajar yang melibatkan peserta didik dalam proses kegiatan mental melalui tukar pendapat, dengan diskusi, seminar, membaca sendiri dan mencoba sendiri, agar anak dapat belajar sendiri. Dengan demikian, situasi belajar mengajar berpindah dari situasi teacher dominated learning menjadi situasi student dominated learning.

\section{METODE}

Penelitian ini menggunakan metode deskriptif kualitatif. Penelitian ini memberikan gambaran tentang model pembelajaran discovery yang digunakan guru dalam mengajar materi teks laporann hasil observasi.

Data dalam penelitian ini adalah ujaran guru dan ujaran siswa yang diperoleh dari hasil pengamatan penulis terhadap aktivitas belajar siswa di kelas X IPA 1 SMA Negeri 4 Lebong menggunakan model pembelajaran discovery. Sumber data dalam penelitian ini adalah guru Bahasa Indonesia (Bapak Edwin Mahendra, S.Pd.) dan siswa kelas X IPA 1 SMA Negeri 4 Lebong.

Teknik pengumpulan data dalam penelitian ini menggunakan empat teknik pengumpulan data, yakni observasi, wawancara, dokumentasi dan teknik rekam.

Instrumen yang digunakan dalam penelitian ini berupa pedoman observasi dan pedoman wawancara. Pedoman observasi digunakan untuk mengukur bagaimana proses pembelajaran dan keaktifan peserta didik sehingga hasilnya nanti akan dideskripsikan. Pedoman wawancara digunakan untuk mengetahui keaktifan belajar siswa dalam mengikuti pembelajaran di kelas, dan kendala-kendala yang dihadapi guru selama pembelajaran. Selain lembar pedoman observasi dan pedoman wawancara, penulis menggunakan instrumen pengumpulan data berupa alat rekam (handphone) yang akan mempermudah proses pengumpulan data sehingga data yang diperoleh lebih akurat. 
Teknik analisis data dalam penelitian ini yaitu menggunakan teknik reduksi data (data reduction), penyajian data (data display) dan penarika kesimpulan (verification). Validitas data dalam penelitian ini menggunakan triangulasi. Kenyataan tersebut memiliki kesamaan dengan penelitian yang dilakukan oleh Septi Pratiwi (2018). Dalam penelitian tersebut menggunakan teknik pemeriksaan keabsahan atau triangulasi data menurut Moleong (1989:195) yang memanfaatkan sesuatu yang lain diluar data itu untuk keperluan pengecekan atau sebagai pembanding terhadap data.

\section{HASIL DAN PEMBAHASAN}

\section{Hasil}

Hasil penelitian ini adalah guru Bahasa Indonesia menggunakan model pembelajaran Discovery pada pelajaran Bahasa Indonesia materi teks laporan hasil observasi di kelas X IPA 1 SMA Negeri 4 Lebong. Akan tetapi tidak semua sintaks model pembelajaran Discovery digunakan guru pada saat proses belajar mengajar berlangsung. Pada pertemuan pertama dengan topik materi mengidentifikasi isi teks laporan hasil observasi guru menggunakan semua sintaks model pembelajaran Discovery, pada pertemuan kedua dengan topik materi mengidentifikasi struktur teks laporan hasil observasi guru tidak menggunakan salah satu sintaks model pembelajaran Discovery yaitu Verification atau pembuktian. Pada pertemuan ketiga dengan topik materi mengidentifikasi unsur kebahasaan teks laporan hasil observasi guru tidak menggunakan dua sintaks model pembelajaran Discovery yaitu Data Collection atau (pengumpulan data) dan Verification atau pembuktian.

\section{a. Stimulation (stimulasi/pemberian rangsangan)}

Laporan hasil pengamatan model pembelajaran Discovery yang digunakan pada proses pembelajaran Bahasa Indonesia siswa di kelas X IPA 1 SMA Negeri 4 Lebong ditemukan bahwa selama tiga kali pertemuan, guru menggunakan model pembelajaran Discovery dan memenuhi sintaks model Discovery learning yang pertama yaitu Stimulation (stimulasi/pemberian rangsangan).

Pada pertemuan pertama, guru menggunakan model pembelajaran Discovery dan memenuhi sintaks model pembelajaran Discovery yang pertama yaitu Stimulation (stimulasi/pemberian rangsangan), hal tersebut dibuktikan dengan percakapan guru yang bertanya kepada siswa apa yang dimaksud dengan teks laporan hasil observasi.

Pada pertemuan kedua, guru menggunakan model pembelajaran Discovery dan memenuhi sintaks model pembelajaran Discovery yang pertama yaitu Stimulation (stimulasi/pemberian rangsangan), hal tersebut dibuktikan dengan percakapan guru yang bertanya kepada siswa apa yang dimaksud dengan isi, struktur dan pertnyataan umum dalam teks laporan hasil observasi.

Pada pertemuan ketiga, guru menggunakan model pembelajaran Discovery dan memenuhi sintaks model pembelajaran Discovery yang pertama yaitu Stimulation (stimulasi/pemberian rangsangan), hal tersebut dibuktikan dengan percakapan guru yang bertanya kepada siswa apa yang dimaskud dengan pernyataan umum, deskripsi bagian dan deskripsi manfaat.

\section{b. Problem Statement (pernyataan/identifikasi masalah)}


Laporan hasil pengamatan model pembelajaran Discovery yang digunakan pada proses pembelajaran Bahasa Indonesia siswa di kelas X IPA 1 SMA Negeri 4 Lebong ditemukan bahwa selama tiga kali pertemuan, guru menggunakan model pembelajaran Discovery dan memenuhi sintaks model pembelajaran Discovery yang kedua yaitu Problem Statement (pernyataan/identifikasi masalah).

Pada pertemuan pertama, guru menggunakan model pembelajaran Discovery dan memenuhi sintaks model pembelajaran Discovery yang kedua yaitu Problem Statement (pernyataan/identifikasi masalah), hal tersebut dibuktikan dengan percakapan guru yang meminta siswa untuk mencari gagasan pokok yang terdapat di dalam paragraf.

Pada pertemuan kedua, guru menggunakan model pembelajaran Discovery dan memenuhi sintaks model pembelajaran Discovery yang kedua yaitu Problem Statement (pernyataan/identifikasi masalah), hal tersebut dibuktikan dengan percakapan guru yang meminta siswa untuk menemukan apa perbedaan dari teks wayang dengan teks suku Badwi dan menentukan struktur dari teks tersebut.

Pada pertemuan ketiga, guru menggunakan model pembelajaran Discovery dan memenuhi sintaks model pembelajaran Discovery yang kedua yaitu Problem Statement (pernyataan/identifikasi masalah), hal tersebut dibuktikan dengan percakapan guru yang meminta siswa untuk menentukan jenis, imbuhan dan kata dasar.

c. Data Collection (pengumpulan data)

Laporan hasil pengamatan model pembelajaran Discovery yang digunakan pada proses pembelajaran Bahasa Indonesia siswa di kelas X IPA 1 SMA Negeri 4 Lebong ditemukan bahwa selama tiga kali pertemuan, guru menggunakan model pembelajaran Discovery dan tidak semua memenuhi sintaks model pembelajaran Discovery yang ketiga yaitu Data Collection (pengumpulan data).

Pada pertemuan pertama, guru menggunakan model pembelajaran Discovery dan memenuhi sintaks model pembelajaran Discovery yang ketiga yaitu Data Collection (pengumpulan data), hal tersebut dibuktikan dengan percakapan guru yang meminta siswa untuk membaca dihalaman dua belas untuk mengumpulkan data atau informasi yang terdapat dalam teks yang dibaca.

Pada pertemuan kedua, guru menggunakan model pembelajaran Discovery dan memenuhi sintaks model pembelajaran Discovery yang ketiga yaitu Data Collection (pengumpulan data), hal tersebut dibuktikan dengan percakapan guru yang meminta siswa untuk menyimak pada saat dibacakannya teks yang berjudul Mengenal Suku Badwi.

Pada pertemuan ketiga, guru menggunakan model pembelajaran Discovery dan tidak memenuhi sintaks model pembelajaran Discovery yang ketiga yaitu Data Collection (pengumpulan data).

d. Data Processing (Pengolahan Data)

Laporan hasil pengamatan model pembelajaran Discovery yang digunakan pada proses pembelajaran Bahasa Indonesia siswa di kelas X IPA 1 SMA Negeri 4 Lebong ditemukan bahwa selama tiga kali pertemuan, guru menggunakan model pembelajaran Discovery dan memenuhi sintaks model pembelajaran Discovery yang keempat yaitu Data Processing (Pengolahan Data).

Pada pertemuan pertama, guru menggunakan model pembelajaran Discovery dan memenuhi sintaks model pembelajaran Discovery yang keempat yaitu Data Processing 
(Pengolahan Data). Hal tersebut dibuktikan dengan percakapan guru yang meminta siswa untuk mengerjakan tugas yang telah diberikan kemudian jawabannya ditulis di depan.

Pada pertemuan kedua, guru menggunakan model pembelajaran Discovery dan memenuhi sintaks model pembelajaran Discovery yang keempat yaitu Data Processing (Pengolahan Data). Hal tersebut dibuktikan dengan percakapan guru yang meminta siswa untuk mengerjakan tugas yang telah diberikan kemudian jawabannya ditulis di depan.

Pada pertemuan ketiga, guru menggunakan model pembelajaran Discovery dan memenuhi sintaks model pembelajaran Discovery yang keempat yaitu Data Processing (Pengolahan Data). Hal tersebut dibuktikan dengan percakapan guru yang meminta siswa untuk mengisi verba, imbuhan dan jenis teks pada tabel yang kosong.

\section{e. Verification (Pembuktian)}

Laporan hasil pengamatan model pembelajaran Discovery yang digunakan pada proses pembelajaran Bahasa Indonesia siswa di kelas X IPA 1 SMA Negeri 4 Lebong ditemukan bahwa selama tiga kali pertemuan, guru menggunakan model pembelajaran Discovery dan tidak semua memenuhi sintaks model Discovery learning yang kelima yaitu Verification (Pembuktian). Hal tersebut dibuktikan dengan percakapan pada proses pembelajaran di kelas yaitu :

Pada pertemuan pertama, guru menggunakan model pembelajaran Discovery dan memenuhi sintaks model pembelajaran Discovery yang kelima yaitu Verification (pembuktian). Hal tersebut dibuktikan dengan percakapan guru yang mengajak siswa bersama-sama memeriksa atau membuktikan jawaban dari masing-masing kelompok apakah sudah benar atau belum.

Pada pertemuan kedua, guru menggunakan model pembelajaran Discovery dan tidak memenuhi sintaks model pembelajaran Discovery yang kelima yaitu Verification (pembuktian).

Pada pertemuan ketiga, guru menggunakan model pembelajaran Discovery dan tidak memenuhi sintaks model pembelajaran Discovery yang kelima yaitu Verification (pembuktian).

\section{f. Generalization (menarik kesimpulan/generalisasi)}

Laporan hasil pengamatan model pembelajaran Discovery yang digunakan pada proses pembelajaran Bahasa Indonesia siswa di kelas X IPA 1 SMA Negeri 4 Lebong ditemukan bahwa selama tiga kali pertemuan, guru menggunakan model pembelajaran Discovery dan memenuhi sintaks model pembelajaran Discovery yang terakhir yaitu Generalization (menarik kesimpulan/generalisasi). Hal tersebut dibuktikan dengan percakapan pada proses pembelajaran di kelas yaitu :

Pada pertemuan pertama, guru menggunakan model pembelajaran Discovery dan memenuhi sintaks model pembelajaran Discovery yang terakhir yaitu Generalization (menarik kesimpulan). Hal tersebut dibuktikan dengan percakapan guru yang mengajak siswa bersama-sama untuk menyimpulkan tentang isi dari teks laporan hasil observasi. Pada pertemuan kedua, guru menggunakan model pembelajaran Discovery dan memenuhi sintaks model pembelajaran Discovery yang terakhir yaitu Generalization (menarik kesimpulan). Hal tersebut dibuktikan dengan percakapan guru yang mengajak siswa 
bersama-sama untuk menyimpulkan tentang apa saja struktur teks laporan hasil observasi.

Pada pertemuan ketiga, guru menggunakan model pembelajaran Discovery dan memenuhi sintaks model pembelajaran Discovery yang terakhir yaitu Generalization (menarik kesimpulan). Hal tersebut dibuktikan dengan percakapan guru yang mengajak siswa bersama-sama untuk menyimpulkan tentang frase, kata, afiksasi pada teks laporan hasil observasi.

\section{Pembahasan}

Berdasarkan situasi dan kondisi pandemi covid-19 yang terjadi saat ini, pembelajaran yang efektif sukar di dapat karena keterbatasan waktu guru dalam menjelaskan materi pelajaran. SMA Negeri 4 Lebong yang terletak di Desa Suka Negeri Kecamatan Topos Kabupaten Lebong merupakan salah satu sekolah yang masih melaksanakan kegiatan belajar mengajar karena merupakan kawasan yang berzona hijau. Namun saat pandemi covid-19 ini sistem pembelajaran di SMA Negeri 4 lebong mengalami sedikit perubahan.

Sebelum pandemi covid-19 waktu guru mengajar 1 jam pelajaran yaitu selama 40 menit, namun saat pandemi covid-19 waktu untuk guru mengajar di kelas dikurangi menjadi 20 menit dan juga siswa secara bergantian untuk datang ke sekolah sesuai dengan nomor absen ganjil genap, pada minggu pertama siswa bernomor absen genap yang boleh belajar disekolah, sedangkan yang bernomor absen ganjil belajar di rumah. Begitu juga minggu berikutnya, siswa bernomor absen ganjil yang belajar di sekolah, sedangkan siswa bernomor absen genap belajar di rumah.

Dalam waktu yang sangat terbatas ini guru dituntut untuk mampu mengajar mulai dari membuka pembelajaran, menjelaskan, bertanya, menggunakan variasi media, memberi penguatan kepada siswa, memberi tugas dan menutup pelajaran. Guru dan siswa juga harus mengikuti protokol kesehatan yaitu menggunakan masker, dan mencuci tangan di sekolah. Dalam hal ini, guru harus memperhatikan bagaimana mengelola kelas dengan pengajaran yang dilalukan. Siswa harus dibuat agar terus-menerus memberikan reaksi pada lingkungan, sehingga pengalaman belajar dapat terjadi sesuai dengan kondisi yang diinginkan walaupun sedang berada dimasa pandemi covid-19 seperti yang terjadi pada saat ini.

Dalam penelitan ini ditemukan bahwa dengan digunakannya model pembelajaran Discovery dapat mendukung partisipasi aktif siswa dalam proses pembelajaran, menumbuhkan rasa ingin tahu siswa, membuat siswa memiliki motivasi yang tinggi karena guru memberikan kesempatan kepada mereka untuk melakukan eksperimen dan menemukan sesuatu untuk diri mereka sendiri, membangun pengetahuan berdasarkan pada pengetahuan awal yang telah dimiliki oleh siswa sehingga mereka dapat memiliki pemahaman yang lebih mendalam, membuat siswa bertanggungjawab terhadap kesalahan-kesalahan dan hasil-hasil yang mereka buat selama proses belajar, mengembangkan keterampilan-keterampilan kreatif dan pemecahan masalah dan juga menemukan hal-hal baru yang menarik yang belum terbayang sebelumnya setelah pengumpulan informasi dan proses belajar yang dilakukan.

Dalam pengamatan ditemukan bahwa model pembelajaran Discovery dapat mengurangi ketergantungan kepada guru sebagai satu-satunya sumber belajar yang diperlukan oleh para siswa, model pembelajaran discovery juga dapat meningkatkan keterlibatan peserta didik secara aktif dalam memperoleh dan memproses perolehan 
belajar. Dengan digunakannya model pembelajaran discovery menyebabkan siswa dapat mengarahkan kegiatan belajarnya sendiri dengan melibatkan akal dan motivasi sendiri. Model pembelajaran ini dapat membantu siswa memperkuat konsep dirinya karena memperoleh kepercayaan bekerja sama dengan teman lainnya. Dalam penelitian ini ditemukan bahwa pembelajaran berpusat pada siswa yang berperan aktif mengeluarkan gagasan-gagasannya.

Data yang dijadikan dasar penelitian ini adalah keterampilan guru saat mengajar mata pelajaran Bahasa Indonesia materi teks laporan hasil observasi pada siswa kelas X IPA 1 SMA Negeri 4 Lebong menggunakan model pembelajaran discovery. Data tersebut diperoleh dari hasil wawancara, observasi dan dokumentasi yang dilakukan di SMA Negeri 4 Lebong pada tanggal 27 agustus 2020 sampai 04 september 2020. Dalam pengamatan ditemukan bahwa guru Bahasa Indonesia sudah menggunakan model pembelajaran Discovery pada setiap pertemuan jam pelajaran Bahasa Indonesia di kelas X IPA 1 SMA Negeri 4 Lebong. Akan tetapi tidak semua sintaks model pembelajaran Discovery digunakan guru pada saat proses belajar mengajar berlangsung.

\section{PENUTUP}

\section{Simpulan}

Berdasarkan hasil penelitian dan pembahasan maka dapat disimpulkan bahwa guru Bahasa Indonesia menggunakan model pembelajaran Discovery pada pelajaran Bahasa Indonesia materi teks laporan hasil observasi di kelas X IPA 1 SMA Negeri 4 Lebong. Akan tetapi tidak semua sintaks model pembelajaran Discovery digunakan guru pada saat proses belajar mengajar berlangsung. Pada pertemuan pertama dengan topik materi mengidentifikasi isi teks laporan hasil observasi guru menggunakan semua sintaks model pembelajaran Discovery, pada pertemuan kedua dengan topik materi mengidentifikasi struktur teks laporan hasil observasi guru tidak menggunakan salah satu sintaks model pembelajaran Discovery yaitu Verification atau pembuktian. Pada pertemuan ketiga dengan topik materi mengidentifikasi unsur kebahasaan teks laporan hasil observasi guru tidak menggunakan dua sintaks model pembelajaran Discovery yaitu Data Collection atau (pengumpulan data) dan Verification atau pembuktian.

\section{Saran}

Berdasarkan kesimpulan yang dikemukakan sebelumnya mengenai Deskripsi Model Discovery Learning Pada Pelajaran Bahasa Indonesia Kurikulum 2013 Materi Teks Laporan hasil Observasi Siswa Kelas X IPA 1 SMA Negeri 4 lebong, penelitian yang dilakukan penulis terbatas pada deskripsi model Discovery Learning yang digunakan oleh guru Bahasa Indonesia mengajar materi teks laporan hasil observasi. Oleh sebab itu penulis berharap agar penelitian selanjutnya bisa meneliti bagaimana prestasi belajar siswa setelah belajar menggunakan model pembelajaran Discovery Learning.

\section{DAFTAR RUJUKAN}

Majid,Abdul dan Chaerul Rochman. 2015. Pendekatan Imiah Dalam Implementasi Kurikulum 2013. Bandung : PT Remaja Rosdakarya.

Pratiwi, Septi. 2018. "Pelaksanaan Model Pembelajaran Berbasis Proyek Pada Pembelajaran Bahasa Indonesia Kurikulum 2013 Kelas VIII Di SMP Negeri 4 Kota Bengkulu”. Jurnal Ilmiah Korpus. Vol.II, No.II, Agustus, hlm. 212. 
Maharini, Gumono, M. Arifin

Roestiyah, N.K. 2012. Strategi Belajar Mengajar. Jakarta : PT Rineka Cipta.

Saefuddin, Asis dan IkaBerdiati. 2014. Pembelajaran Efektif. Bandung: PT Remaja Rosdakarya.

Suryosubroto. 2002. Proses Belajar Mengajar di Sekolah. Jakarta: PT Rineka Cipta. 